\title{
Correlations between molecular parameters of guest substances and their effect on model lipid membranes
}

\author{
A.O.Sadchenko, O.V.Vashchenko, N.A.Kasian, \\ L.V.Budianska, L.N.Lisetski
}

Institute for Scintillation Materials, STC "Institute for Single Crystals", National Academy of Sciences of Ukraine, 60 Lenina Ave., 61001 Kharkiv, Ukraine

\author{
Received April 7, 2016
}

Effect of guests molecules on phase transitions of model lipid membranes was studied by differential scanning calorimetry. Membranotropic action of guest molecules was estimated from the shift of "gel - liquid crystal" phase transition temperature of lipid membranes. Relationships between membranotropic action and molecular parameters of guest molecules (volume, surface area, dipole moment, anisometry, lipophilicity coefficient, fraction of the polar area, etc.) were examined. For most of the lipophilic substances studied a high linear correlations between membranotropic action and lipophilicity coefficient $(r=0.86)$, as well as fraction of polar molecular area $(r=-0.83)$ were established. For hydrophilic substances such correlations were not found. For groups of substances with similar chemical nature (glycerol derivatives, ammonium compounds), high linear correlations $(r>0.8)$ were established between membranotropic action and such molecular parameters as surface area, volume, dipole moment.

Keywords: liquid crystal, lipid membranes, differential scanning calorimetry, hydrofobic, hydrophilic substances.

Методом дифференциальной сканирующей калориметрии исследовано влияние различных добавок на фазовые переходы модельной липидной мембраны. Мембранотропное действие добавки оценивалось по сдвигу температуры фазового перехода "гель - жидкий кристалл" липидной мембраны. Рассмотрена связь мембранотропного действия добавки с её молекулярными параметрами (объём, площадь поверхности, дипольный момент, степень анизометрии, коэффициент липофильности, доля полярной поверхности молекулы и др.). Установлена высокая линейная корреляция мембранотропного действия с коэффициентом липофильности $(r=0.86)$, а также долей полярной поверхности молекулы $(r=$ -0.83). Для гидрофильных веществ подобные корреляции не обнаружены. Для групп веществ близкой химической природы (аммониевых соединений и производных глицерина) установлена высокая линейная корреляция $(r>0.8)$ мембранотропного действия с такими параметрами, как площадь поверхности, объём и дипольный момент.

Кореляції між молекулярними параметрами речовин та їх дією на модельні ліпідні мембрани. А.О.Садченко, О.В.Ващенко, Н.О.Касян, Л.В.Будянська, Л.М.Лисецький.

Методом диференціальної скануючої калориметрії досліджено вплив різних домішок на фазові переходи модельної ліпідної мембрани. Мембранотропну дію домішки оцінено 3 зсувом температури фазового переходу "гель - рідкий кристал" ліпідної мембрани. Розглянуто зв'язок мембранотропної дії з молекулярними параметрами домішок (об'єм, площа поверхні, дипольний момент, ступінь анізометрії, коефіцієнт ліпофільності, частка полярної поверхні молекули, тощо.). Встановлено високу лінійну кореляцію мембранотропної дії з коефіцієнтом ліпофільності $(r=0,86)$, а також часткою полярної поверхні молекули $(r=-0,83)$. Для гідрофільних домішок такі кореляції не виявлено. Для груп речовин близької хімічної природи (амонійові сполуки, похідні гліцерину) встановлено високу лінійну кореляцію $(r>0.8)$ мембранотропної дії з такими параметрами, як площа поверхні, об'єм, дипольний момент. 


\section{Introduction}

One of important and, at the same time, difficult problems of materials science is correlation between properties of a composite material and features of its components. Materials based on water-lipid structures, viz., liposomes, micelles, bilayers, etc., are widely used now for both fundamental and applied research with important biomedical applications, such as liposomal drug delivery systems [1-3]. Drug - lipid interactions problem gained substantial topicality in the last decades [4-6]. One of the important aspects under consideration is the influence of drugs (or other guest molecules) on properties of lipid membranes, which is commonly designated as membranotropic effect.

The membranotropic effect depends on a variety of factors including molecular parameters of guest molecules, so its prediction appears as an unconventional problem. At present, only qualitative comparison of membranotropic effects in relationship to particular molecular features could be found in literature. So the task of the present study was to analyze various molecular parameters of guest molecules in lipid membranes, pointing out those that could be the most important and determinative for membranotropic action.

Our concept of considering model phospholipid membranes as a sort of functional materials promising for their use in drug discovery studies was recently substantiated in [7], where phosphatidylcholine-based stationary phases were used in artificial immobilized membrane (IAM) chromatography.

\section{Materials and methods}

Membranotropic effects of about 30 various substances were studied by means of differential scanning calorimetry (DSC) in model membranes of hydrated $L$ - $\alpha$-dipalmitoylphosphatidilcholine (DPPC) with water content 65 wt. \%. For DSC measurements, a Mettler DSC 1 microcalorimeter was used, and two scanning cycles "cooling - heating" at $2 \mathrm{~K} / \mathrm{min}$ were performed for each sample in the temperature range of the DPPC membrane pre- and main phase transitions. The temperature of the main phase transition (or "gel - to - liquid crystal" transition), $T_{m}$, should be especially noted as a primary parameter for evaluation of membranotropic effects.

In order to compare the results of different experiments, the membranotropic activity parameter $\left(a_{m}\right)$ was suggested [24]. It corresponds to the change in $T_{m}$ resulting from introduction of $1 \% \mathrm{w} / \mathrm{w}$ of a certain substance into the membrane:

$$
a_{m}=\frac{\Delta T_{m}}{c}
$$

were $\Delta T_{m}$ is the shift of $T_{m}$ under introduction of the guest substance, $c$ is the weight concentration of the guest substance with respect to dry DPPC. The mass-additive concentration term was chosen because the absence of chemical or other specific interactions in the system was assumed as first approximation.

The lipophilicity coefficient, $\log P$, was estimated using Virtual Computing Chemical Laboratory [8]. We have used seven different techniques, such as Pharma Algorithm (AC_logP), Molinspiration Algorithms (miLogP, ALOGP, MLOGP; soft DragonX) [9,10], XLOGP2 and XLOGP3 (soft XLOGP2, XLOGP3) [11] as well as ALOGPs (soft ALOGPS 2.1) [12].

Such molecular parameters as total area $\left(S_{\text {total }}\right)$, volume $\left(V_{m}\right)$, dipole moment $(\mu)$ and geometrical dimensions $\left(r_{x}, r_{y}, r_{z}\right)$ were calculated by semiempirical method AM1 using software MOPAC 2012, version $15.347 \mathrm{~W}$ [13]. Parameter Spolar was obtained from [14].

Basing on these values, a number of molecular parameters were calculated, such as fraction of the polar area $\left(S_{\text {polar }} / S_{\text {total }}\right)$, as well as molecular anisometry $(k)$, and anisotropic interaction area $\left(S_{k}\right)$, which were obtained, according to [23], as

$$
\begin{gathered}
k=\frac{r_{z}-r_{x y}}{r_{z}+r_{x y}}, \\
S_{k}=k \cdot S_{t o t a l},
\end{gathered}
$$

where $r_{z}$ is the largest linear dimension of the molecule, $r_{x y}$ is the largest dimenstion from $r_{x}$ and $r_{y}$. Parameter $k$ is 0 for spherical molecular shape and close to 1 for the rod-like shape. Parameter $S_{k}$ is intended to take into account molecular size.

Matrices of linear correlation coefficients were compiled for various groups of substances. Correlation coefficients $r$ between parameters $\mathrm{X}$ and $\mathrm{Y}$ were obtained as

$$
r(x, y)=\frac{\sum(x-\bar{x})(y-\bar{y})}{\sqrt{\sum(x-\bar{x})^{2} \sum(y-\bar{y})^{2}}}
$$




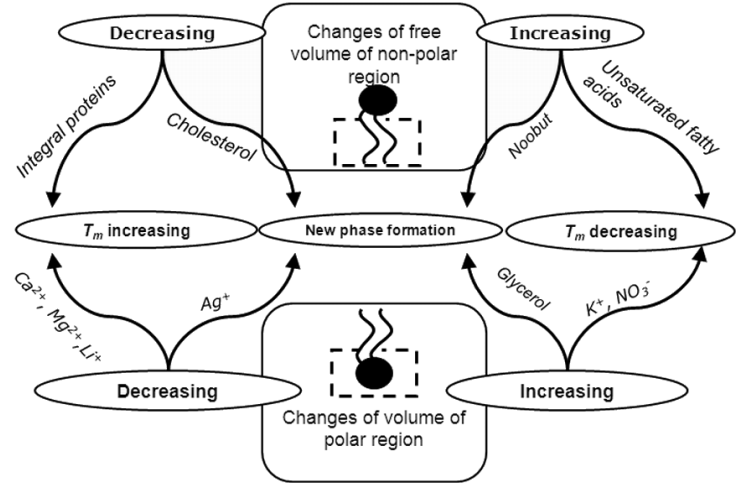

Fig. 1. Classification of membranotropic effects (with examples).

were $\bar{x}$ and $\bar{y}$ are the mean values in the group. Linearity of the correlation is provided by relatively small concentration of the substance used for $a_{m}$ determination.

\section{Results and discussion}

Our tentative classification of membranotropic effects made on the basis of both literature and our own data [15-24] is presented in Fig. 1. Two main mechanisms of the membranotropic effects could be specified, namely, (1) primary interaction of the drug molecule with the hydrophobic part of lipids ("absorption") and (2) primary interaction to the hydrophilic part of lipids ("adsorption"). Such interactions result in changes in the cross-section (1) of non-polar part of lipid molecule and corresponding increasing/decreasing of free volume, and (2) of polar part of the molecule due to hydration/dehydration processes, respectively. Since the main condition of the membrane planarity is cylindrical shape of lipid molecules, changes in one part of the membrane imply changes in another one. Within both mechanisms, increase or decrease of $T_{m}$ could be observed, as well as formation of new phases. The later process implies lateral lipid separation (which is manifested as appearance of an additional phase transition peak, like for $\mathrm{Ag}^{+}$and for the drug noobut [20]) and formation of a new thermodynamic phase, like for glycerol [25]).

Analysis of literature and our experimental data allowed us to select and classify the factors defining membranotropic action of individual substances (Fig. 2). It is clear that chemical structure and geometric parameters of a molecule are $a$ priori important for all its properties. Also, the electrostatic properties should be significant as far

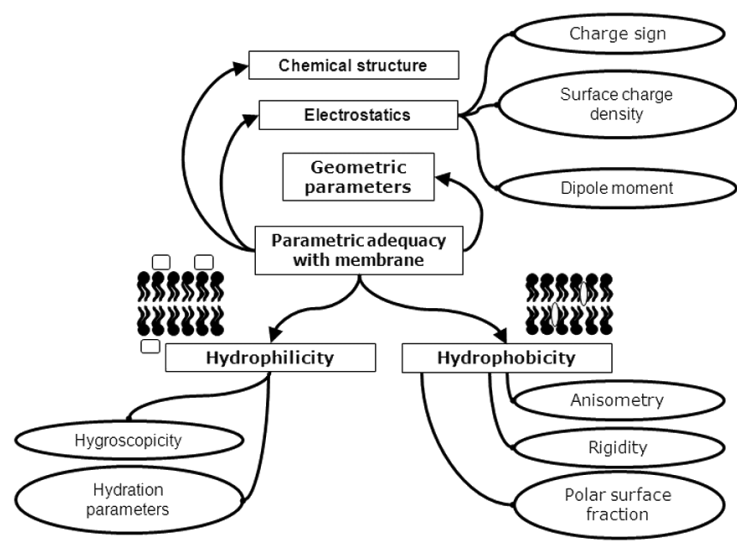

Fig. 2. Molecular parameters essential for membranotropic action.

as electrostatic interactions are the most powerful among non-covalent ones.

Lipophilicity is generally acknowledged as an important parameter. We consider that lipophilicity of a molecule generally determines its interactions with the membrane by adsorption or absorption mechanism. Hydrophylic molecules are mostly adsorbed at the lipid-water interface, whereas lipophylic ones are absorbed, partially or fully, into the membrane bulk. So, for lipophylic substances, the most significant effects should be related to the same molecular parameters that are known to be important for nonmesogenic dopants in thermotropic liquid crystals, namely, anisometry and rigidity [26]. In addition, we suggest another molecular parameter, the polar surface fraction which is defined as the ratio of molecular polar surface area to the total molecular surface area $\left(S_{\text {polar }} / S_{\text {total }}\right)$. Generally, both $S_{\text {polar }} / S_{\text {total }}$ and $<\log P>$ reflect hydrophilic/hydrophobic properties of the molecule. For hydrophilic substances, various hydration parameters are important, including hygroscopicity [27, 28], cosmotropicity $[17,29]$, etc. Finally, the parametric adequacy between corresponding parameters of the membrane and the molecule become important [30, 31].

Coefficients of linear correlations between $\log P$ values obtained by various techniques and parameter $a_{m}$ obtained by Eq. (1) were calculated (see Part 2). For the whole set of the substances examined, the correlations were found to be rather weak and unreliable $(r=-0.22 \div-0.42)$. In our opinion, this result just confirms that membranotropic effects are caused not by lipophilicity only, but by the diversity of the molecular parameters (see Fig. 2). Besides, different techniques of $\log P$ calculation gave rather 


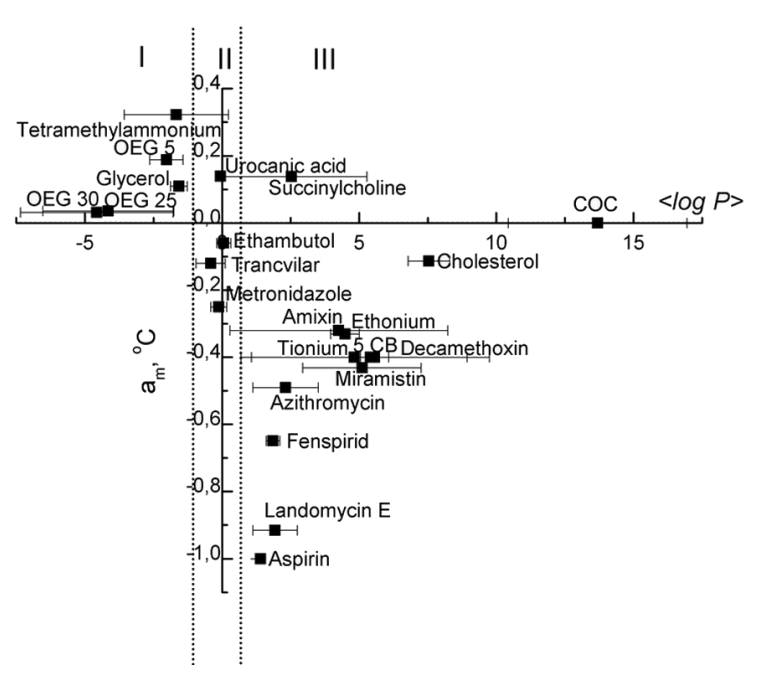

Fig. 3. Mean lipophilicity coefficient and membranotropic activity of guest substances in the DPPC membrane.

different values, so for further analysis we used the average $\log P$ values $(<\log P>$ ).

Collecting of $<\log P>$ and $a_{m}$ data (Fig. 3) allows us to select 3 groups of substances: with $<\log P><0$ (I), with $<\log P>\sim 0$ (II), and with $<\log P>>0$ (III). For group III, with $<\log P>$ from 1 to 14 , negative $a_{m}$ are typical, and high linear correlation $(r=0.86)$ was obtained between $<\log P>$ and $a_{m}$. The molecules in this group are apparently absorbed by the lipid membrane. The only exception is succynilcholine, a dication that is most likely adsorbed at lipid/water interface. All the substances with negative $<\log P>$ values (group I) are polar/charged, so they are expected to be adsorbed at the membrane surface, without penetration into the inner part of the membrane. Positive $a_{m}$ values are typical for this group. If $<\log P>\sim 0$ (group II), both negative and positive $a_{m}$ values were registered. Obviously, other molecular pa-

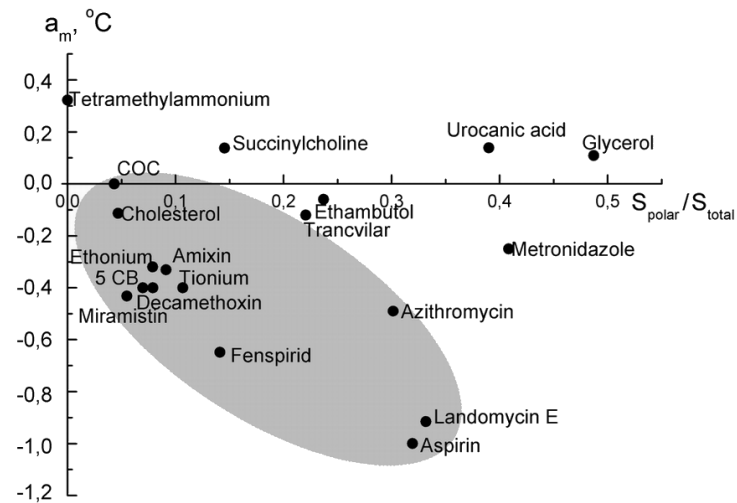

Fig. 4. Molecular polar surface fraction and membranotropic activity of guest substances in the DPPC membrane.

rameters become determinative for such substances.

In Fig. 4, the data on $a_{m}$ and $S_{\text {polar }} / S_{\text {total }}$ are collected for the substances examined, except of OEGs (because for them no $S_{\text {polar }}$ values were available). The large group of substances could be separated (marked by grey oval) where reverse correlation between am and $S_{\text {polar }} / S_{\text {total }}$ takes place. This group exactly corresponds to group III (Fig. 3 ). For the other substances, $a_{m}$ seems independent on $S_{\text {polar }} / S_{\text {total }}$. Generally, in the case of "absorption" the higher $S_{\text {polar }} / S_{\text {total }}$ value, the more disturbing could be their effect on the lipid chains packing. This effect appears as negative $a_{m}$, so the dependence $a_{m}$ vs. $S_{\text {polar }} / S_{\text {total }}$ should be reverse. In the case of "adsorption" the molecule appears to be exposed into the water bulk, so it has wide opportunities to contact with polar interior without direct disturbance of the lipid tails packing. Thus, in this case values $a_{m}$ should be largely independent from $S_{\text {polar }} / S_{\text {total }}$. We would also remark that such strict separation by adsorption/absorption mechanisms is rather for-

Table 1. Matrix of linear correlation coefficients between some molecular parameters and membranotropic action for the hydrophobic substances from group III (Fig. 3)

\begin{tabular}{|c|c|c|c|c|c|c|c|c|}
\hline Parameters & $a_{m}$ & $<\log P>$ & $S_{\text {total }}$ & $V_{m}$ & $\mu$ & $k$ & $S_{\text {polar }} / S_{\text {total }}$ & $S_{k}$ \\
\hline$a_{m}$ & 1.00 & 0.86 & 0.46 & 0.41 & -0.40 & -0.39 & -0.83 & 0.43 \\
\hline$<\log P>$ & & 1.00 & 0.16 & 0.41 & -0.38 & 0.41 & -0.67 & 0.51 \\
\hline$S_{t o t a l}$ & & & 1.00 & 0.96 & 0.11 & 0.50 & -0.25 & 0.79 \\
\hline$V_{m}$ & & & & 1.00 & 0.22 & 0.27 & -0.09 & 0.60 \\
\hline$\mu$ & & & & & 1.00 & -0.16 & 0.45 & -0.13 \\
\hline$k$ & & & & & & 1.00 & -0.64 & 0.90 \\
\hline$S_{\text {polar }} / S_{\text {total }}$ & & & & & & & 1.00 & -0.50 \\
\hline$S_{k}$ & & & & & & & & 1.00 \\
\hline
\end{tabular}


Table 2. Matrix of linear correlation coefficients between molecular parameters and membranotropic action for the group of bisquaternary ammonium compounds (decamethoxinum, aethonium, tionium)

\begin{tabular}{||c|c|c|c|c|c|c||}
\hline \hline Parameters & $a_{m}$ & $<\log P>$ & $S_{\text {total }}$ & $V_{m}$ & $\mu$ & $S_{\text {polar }} / S_{\text {total }}$ \\
\hline$a_{m}$ & 1.00 & -0.86 & -0.96 & -0.81 & -0.99 & -0.29 \\
$<\log P>$ & & 1.00 & 0.96 & 1.00 & 0.91 & -0.25 \\
$S_{\text {total }}$ & & & 1.00 & 0.94 & 0.99 & 0.02 \\
$V_{m}$ & & & & 1.00 & 0.88 & -0.32 \\
$\mu$ & & & & 1.00 & 0.17 \\
$S_{\text {polar }} / S_{\text {total }}$ & & & & & & 1.00 \\
\hline \hline
\end{tabular}

mal because it is hardly applicable to more complex molecular structures (e.g., proteins). Nevertheless, we consider it suitable for a large variety of the substances studied since their molecules are not very large (75 to $750 \mathrm{Da}$ ) as compared to DPPC (734.1 Da).

Matrices of linear correlation coefficients, $r$, obtained by Eq. (4), were compiled for various groups of substances (Tables 1-3). Parameters of the hydrophobic substances from group III (see Fig. 3) are considered in Table 1. It should be noted, that this group consists of the substances of various chemical structure, geometrical parameters $\left(S_{t o}\right.$ tal, $\left.V_{m}\right)$, anisometry $(k=0.01 \div 0.74)$ and dipole moments $(\mu=0 \div 8.5)$, though of not very large molecular masses (see above). Taking into account such variety of properties, high linear correlation between $a_{m}$ and $S_{\text {polar }} / S_{\text {total }}(r=0.86)$ as well as between am and $S_{\text {polar }} / S_{\text {total }} \quad(r=-0.83)$ seems rather impressive.

Surprisingly, the anisometry parameters, $k$ and $S_{k}$, obtained by Eqs. $(2,3)$, becomes moderately related to $a_{m}(r=-0.39$ and $r=$ 0.43 , correspondingly). This suggests that anisometry is not so determinative for membranotropic action as for thermotropic mesogens, probably due to more complex character of molecular ordering in the lipid membrane. Very high correlation between $S_{\text {total }}$ and $V_{m}(r=0.96)$ may serve as reference of the calculation adequacy.

More correlations can be observed in the groups of substances with similar chemical nature, viz., in ammonium compounds (Table 2) and glycerol derivatives (Table 3). For these groups, parameters $k$ and $S_{k}$ were excluded from consideration because of high conformation mobility of these molecules. As one can see from Tables 2, 3, high correlations were obtained of $a_{m}$ with a number of molecular parameters, viz., $S_{\text {total }}, V_{m}$ and $\mu(r=-0.81 \div-0.99)$. The negative sign of the correlations indicates that with higher $S_{\text {total }}, V_{m}$ and $\mu$ of the guest molecule, the disturbance induced in lipid membrane becomes more pronounced, so $a_{m}$ values are more negative.

Thus, for hydrophobic substanses $(<\log P>\geq 1$ ) with preferential absorption mechanism, high correlations of $a_{m}$ vs. $S_{\text {polar }} / S_{\text {total }}$ and $a_{m} v s$. $<\log P>$ were observed. For substances with adsorption mechanism $(<\log P><1)$ such correlations were not revealed. In general, all the correlations established seem reasonable from the physical point of view.

\section{Conclusions}

The ability of various chemical substances to affect DPPC model lipid membrane (defined by their melting temperature shift per unit dopant concentration, $a_{m}$ ) was considered.

The presence of linear correlations between $a_{m}$ and a number of molecular parameters $\left(S_{\text {total }}, V_{m}, \mu,<\log P>\right.$, etc.) was examined. Matrices of linear correlation coefficients were obtained for various groups of substances. High linear correlations $(|r| \sim 0.8 \div 0.9)$ were established between $a_{m}$ and $S_{\text {polar }} / S_{\text {total }}$ as well

Table 3. Matrix of linear correlation coefficients between molecular parameters and membranotropic action for the group of glycerol and its derivatives $\left(\mathrm{OEG}_{\mathrm{n}=5}\right.$, $\mathrm{OEG}_{\mathrm{n}=25}, \mathrm{OEG}_{\mathrm{n}=30}$ )

\begin{tabular}{|c|c|c|c|c|c||}
\hline $\begin{array}{c}\text { Parame- } \\
\text { ters }\end{array}$ & $a_{m}$ & $<\log P>$ & $S_{\text {total }}$ & $V_{m}$ & $\mu$ \\
\hline$a_{m}$ & 1.00 & 0.84 & -0.81 & -0.82 & -0.87 \\
$<\log P>$ & & 1.00 & -1.00 & -1.00 & -0.92 \\
$S_{\text {total }}$ & & & 1.00 & 1.00 & 0.94 \\
$V_{m}$ & & & & 1.00 & 0.93 \\
$\mu$ & & & & & 1.00 \\
\hline
\end{tabular}

Functional materials, 23, 2, 2016 
as $a_{m}$ and $<\log P>$ for hydrophobic substances of various nature. Two cases could be distinguished, with $S_{\text {polar }} / S_{\text {total }}$ affecting or not affecting am, which correspond to "absorption" or "adsorption" mechanisms of guest molecules interactions with lipid membrane. Thus, the suggested parameter $S_{\text {polar }} / S_{\text {total }}$ could be informative and appropriate for membranotropic effects determination.

For groups of substances with similar chemical nature (glycerol derivatives, ammonium compounds), high correlations $(r>0.9)$ were established between $a_{m}$ and other molecular parameters $\left(S_{\text {total }}, V_{m}\right.$ and $\mu$ ).

The results obtained could be useful for drug-membrane interactions study and development of modern pharmaceutics.

\section{References}

1. G.Pabst, Biophys. Rev. Lett., 1, 57 (2006).

2. C.Peetla, A.Stine, V.Labhasetwar, Mol. Pharm., 6, 1264 (2009).

3. R.Pignatello, T.Musumeci, L.Basile et al., J. Pharm. Bioallied Sci., 3, 4 (2011).

4. J.K.Seydel, M.Wiese, Drug-Membrane Interactions: Analysis, Drug Distribution, Modeling, Wiley-VCH Verlag GmbH \& Co. KgaA (2002).

5. P.V.Escriba, Trends Mol.Med., 12, 34 (2006).

6. N.Fang, V.Chan, H.Q.Mao, K.W.Leong, Biomacromolecules, 2, 1161 (2001)

7. F.Tsopelasa, Th.Vallianatou, A.Tsantili-Kakoulidou, Expert Opinion on Drug Discover (2016).

doi: $10.1517 / 17460441.2016 .1160886$

8. Electronic resource http:/www.vcclab.org.

9. I.Moriguchi, Chem.Pharm.Bull, 40, 127 (1992).

10. V.N.Viswanadhan, J.Chem. Inf.Comput.Sci., 29, 163 (1989).

11. I.V.Tetko, Drug Discov.Today, 10, 1497 (2005).
12. I.Tetko, J.Chem.Inf.Comput.Sci., 42, 1136 (2002).

13. M.Schmidt, J.Comp.Chem., 14, 1347 (1993).

14. Free Electronic Resource http://pubchem.ncbi.nlm.nih.gov.

15. V.G.Ivkov, G.N.Berestovski, Dynamic Structure of the Lipid Bilayer, Nauka, Moscow (1981) [in Russian].

16. T.G.Anderson, H.M.McConnell, Biophys.J., 81, 2774 (2001).

17. J.H.Ipsen, O.G.Mouritsen, M.Bloom, Biophys. J., 57, 405 (1990).

18. J.A.Veiro, P.Nambi, L.L.Herold et al., Biochim. Biophys. Acta, 900, 230 (1987).

19. A.Nowacka, S.Douezan, L.Wads et al., Soft Matter., 8, 1482 (2012).

20. O.V.Vashchenko, Iu.L.Iermak, L.N.Lisetski, Biophysics, 58, 515 (2013).

21. O.V.Vashchenko, Iu.L.Iermak, A.O.Krasnikova et al., Biophysics, 60, 307 (2015).

22. N.A.Kasian, A.O.Krasnikova, O.V.Vashchenko et al., Biopolymers and Cell, 31, 146 (2015).

23. A.O.Krasnikova, O.V.Vashchenko, N.A.Kasian et al., 4th International Conference Nanobiophysics: Fundamental and Applied Aspects, Kyiv, Ukraine (2015), p.46.

24. L.N.Lisetski, O.V.Vashchenko, N.A.Kasian et al., Nanobiophysics: Fundamentals and Applications, ed. by V.A.Karachevtsev, Pan Stanford Publishing (2016).

25. T.Mavromoustakos, P.Chatzigeorgiou, C.Koukoulitsa et al., Intern. J. Quant. Chem., 111, 1172 (2011).

26. L.N.Lisetski, L.N.Zavora, N.A.Kasian et al., Mol.Cryst. Liq. Cryst., 510, 1240 (2009).

27. O.Vashchenko, V.Pashynska, M.Kosevich et al., Mol.Cryst. Liq. Cryst., 507, 155 (2011).

28. O.V.Vashchenko, A.O.Krasnikova, N.A.Kasian et al., VI convention of UBFT, Lutsk-Svityaz, Ukraine (2015), p.41.

29. K.D.Collins, Methods, 34, 300 (2004).

30. J.A.Killian, Biochim.Biophys.Acta., 1376, 401 (1998).

31. A.Helenius, K.Simons, Biochim.Biophys.Acta, 415, 29 (1975). 